\title{
THE CARDIOVASCULAR RESPONSES TO THE ADDITION OF NITROUS OXIDE TO DIETHYL ETHER IN MAN*
}

\author{
N. TY SMITH, M.D., \\ EDMOND I. EGER, II, M.D., t \\ George A. Gregony, M.D., \\ Bruce F. Cullen, M.D., $\ddagger$ \\ AND \\ Davi J. Cullen, M.D.,
}

IN MAN, THE ADDITION of nitrous oxide to halothane-oxygen anaesthesia produces vasoconstriction and other signs of sympathetic activation. ${ }^{1}$ One cannot say that this sympathetic activation is an independent effect of $\mathrm{N}_{2} \mathrm{O}$ rather than the result of an interdependent action of halothane and $\mathrm{N}_{2} \mathrm{O}$. Nitrous oxide is rarely used as the sole anaesthetic agent, but is commonly used with other agents, including diethyl ether. Therefore, the study of the interaction of $\mathrm{N}_{2} \mathrm{O}$ with several different anaesthetic agents assumes clinical as well as theoretical importance. In this investigation, we examined the effect of the addition of $\mathrm{N}_{2} \mathrm{O}$ to diethyl ether, an anaesthetic agent with an entirely different cardiovascular and sympathetic response from that of halothane.

\section{METHODS}

Eight fasting, unpremedicated healthy male volunteers, aged 21 to 34 years were studied. The investigation was approved by the human study committees of both medical schools. A detailed informed consent was obtained from each subject.

Methods used in this study have been published previously, ${ }^{1.2}$ but a brief description follows. Studies were begun early in the morning, following a 12hour fast. Under local anaesthesia, catheters were placed into the brachial or radial arteries and into the right atrium. The position of the right atrial catheter was confirmed by observing a right ventricular pressure trace and then withdrawing the catheter slightly until the recording returned to venous levels. The following variables were recorded continuously ${ }^{1,2}$; arterial and right atrial pressures; electrocardiogram; phonocardiogram and external carotid pulse by microphones; end-tidal $\mathrm{CO}_{2}$ and ether concentrations by infra-red analyzers; and skin (hand) and oral or oesophageal temperatures by thermistors. Cardiac output was measured intermittently by the dye-dilution technique; arterial $p \mathrm{H}, \mathrm{PO}_{2}$ and $\mathrm{PCO}_{2}$ by electrodes; and forearm and finger blood flows by venous occlusion 01A.

'Supported in part by usphs Crant GM 12527-05, 5TI GM 00063-11, and 1 P01 cM 15571-

thecipient of Nur Research Career Development Award IK3 GM 31757-05. Dr. Smith is from the Department of Anzesthesia, Stanford Medical School, Stanford, Califomia.

\$From the University of California, San Francisco, Califormia-

Canad. Anaesth. Soc. J., vol. 19, no. 1, January 1972. 
plethysmography. All measurements were recorded on Grass and Offner oscillographs; several were recorded on an Ampex FR 1300 magnetic tape recorder. Numerous other variables were calculated from the recorded measurements, such as heart rate, stroke volume, left ventricular minute work, left ventricular stroke work, left ventricular stroke power, ejection time, ejection time index, forearm vascular resistance, and forearm venous compliance.

Anaesthesia was induced with cyclopropane and maintained with diethyl etheroxygen. Ventilation was controlled, since the addition of $\mathrm{N}_{2} \mathrm{O}$ depressed ventilation and altered $\mathrm{PaCO}_{2}$. Alveolar $\mathrm{PCO}_{2}$ was held between 35-38 torr. Ether-oxygen anaesthesia was administered for three hours prior to the addition of $\mathrm{N}_{2} \mathrm{O}$. Endtidal ether concentration and cardiovascular variables were stable for one hour preceding the addition of $\mathrm{N}_{2} \mathrm{O}$.

The ether-oxygen mixture was then changed either to ether-nitrous oxide (70 per cent)-oxygen "; or to ether ( 4.5 per cent)-nitrogen ( 70 per cent)-oxygen. The latter mixture was maintained for 15 minutes and then nitrous oxide was substituted for nitrogen. In either case, $\mathrm{N}_{2} \mathrm{O}$ was administered for only 15 minutes. Immediately before and 15 minutes after each change in inspired mixture, all variables were recorded, and arterial bload was withdrawn for measurement of $p \mathrm{H}, \mathrm{PCO}_{2}$ and $\mathrm{Po}_{2}$. The end-tidal concentration of ether was kept constant, usually necessitating a decrease in inspired concentration when $\mathrm{N}_{2} \mathrm{O}$ was added. The cross-over effect of 70 per cent $\mathrm{N}_{2} \mathrm{O}$ on the infra-red ether analyzer was subtracted from the ether reading. End-tidal samples of ether were aspirated by turning a stopcock interposed between a suction source and the infra-red analyzer. Inspired oxygen concentration was measured with a paramagnetic analyzer.

Nitrous oxide was added at 4.5 per cent and 3.0 per cent end-tidal ether, that is at 2.1 and at $1.5 \mathrm{MAC}^{3}$ Nitrogen was added only at 4.5 per cent ether. Changes in mixture were always performed first at the deeper level.

All data were analyzed with a paired or unpaired Students' $t$ test. The level of significance chosen was $p<0.05$.

\section{Results}

Except for $\mathrm{PaO}_{2}$, blood gas values remained constant during the changes in inspired mixture (Table I). Oesophageal temperature also remained stable. The pupils were large during ether-oxygen anaesthesia, and increased only slightly with the addition of $\mathrm{N}_{2} \mathrm{O}$.

Tables II and III summarize the data obtained when the oxygen concentration or the anaesthetic mixture was changed. All results are given in percent change from the value determined immediately before the change was effected. Standard deviations are given, along with the significance of each circulatory response to the change in oxygen concentration or anaesthesia. In Table III the data are divided according to the concentration of ether and the significance of the difference in response between the two depths is listed in the 7th column. The 8th10th columns list the results when the data from both concentrations are pooled.

\footnotetext{
-Oxygen concentration was always 24.5 per cent. Therefore $\mathrm{N}_{2} \mathrm{O}$ concentration was either 70
} per cent or 71.5 per cent depending on the concentration of ether. 


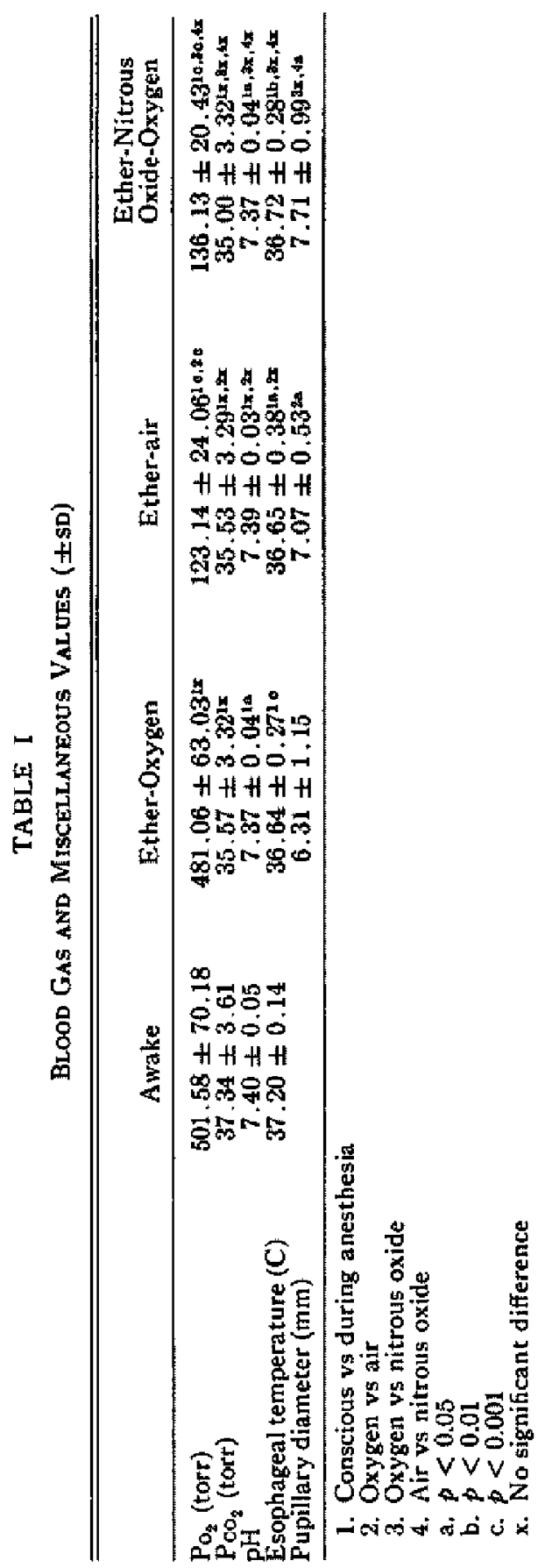


TABLE II

Responses to a Change in Oxygen Concentration from 95.5 per cent to 25.5 PER CENT (4.5 PER CENT END-TIDAL CONCENTHATION ETHER)

\begin{tabular}{lrrc}
\hline \hline & $\begin{array}{c}\text { Per cent } \\
\text { change }\end{array}$ & SD & $\begin{array}{c}\text { Significance } \\
\text { of change }\end{array}$ \\
\hline Cardiac output & 2.80 & 6.90 & Ns* $^{*}$ \\
Heart rate & 6.49 & 7.58 & $p<0.05$ \\
Stroke volume & -3.23 & 6.96 & Ns \\
Mean arterial pressure & -3.79 & 8.80 & NS \\
Mean right atrial pressure (torr) & -0.71 & 1.25 & Ns \\
Systemic vascular resistance & -5.09 & 11.54 & NS \\
Left ventricular minute work & -1.20 & 10.40 & Ns \\
Left ventricular stroke work & -6.87 & 10.46 & Ns \\
Left ventricular stroke power & -7.47 & 11.23 & Ns \\
Ejection time index & 1.99 & 2.85 & Ns \\
Mean rate left ventricular ejection & -2.50 & 6.44 & NS \\
Tension-time index & -4.43 & 9.27 & Ns \\
Forearm vascular resistance & 3.93 & 32.44 & Ns \\
Forearm blood fow & 17.78 & 58.10 & Ns \\
Forearm venous pressure & 3.75 & 12.91 & Ns \\
Forearm venous compliance & 16.65 & 61.23 & \\
\hline
\end{tabular}

*NS $=$ not significant

Reducing the concentration of oxygen by adding nitrogen significantly affected only the heart rate, which increased (Table II). Addition of nitrous oxide to 3 per cent ether in oxygen produced no circulatory changes (Table III). On the other hand, addition of nitrous oxide to 4.5 per cent ether increased mean arterial pressure, systemic vascular resistance, left ventricular minute work, left ventricular stroke work, and tension-time index.

\section{Discussion}

In a conscious human subject, a decrease in inspired oxygen concentration from 100 to 30 per cent increases heart rate, cardiac output, and left ventricular minute work, and decreases systemic vascular resistance." All of these changes except the increase in heart rate were obtunded by ether. This has also been reported for halothane anaesthesia. ${ }^{1}$

The circulatory response to the addition of nitrous oxide to 4.5 per cent endtidal ether anaesthesia is similar to that seen with halothane', that is, slight vasoconstriction without cardiac stimulation. In the case of halothane, the response could be attributed to an increased sympathetic discharge triggered by $\mathrm{N}_{2} \mathrm{O}$, as indicated by pupillary dilatation, a rise in oesophageal temperature, and an increase in serum norepinephrine levels. However, with diethyl ether the evidence is not so clear, since little change in pupillary diameter and no change in oesophageal temperature were seen. The pupillary dilatation may have been limited by the pre-existing dilatation induced by ether.

There are factors which could increase or decrease the response to $\mathrm{N}_{2} \mathrm{O}$ with ether as compared with halothane. Halothane depresses the sympathoadrenal response to circulatory depression, while ether does not diminish this response and perhaps even stimulates it. ${ }^{5}$ Therefore, if the response to $\mathrm{N}_{2} \mathrm{O}$ were due to a sympathetic discharge, one might expect to see a greater response with ether 


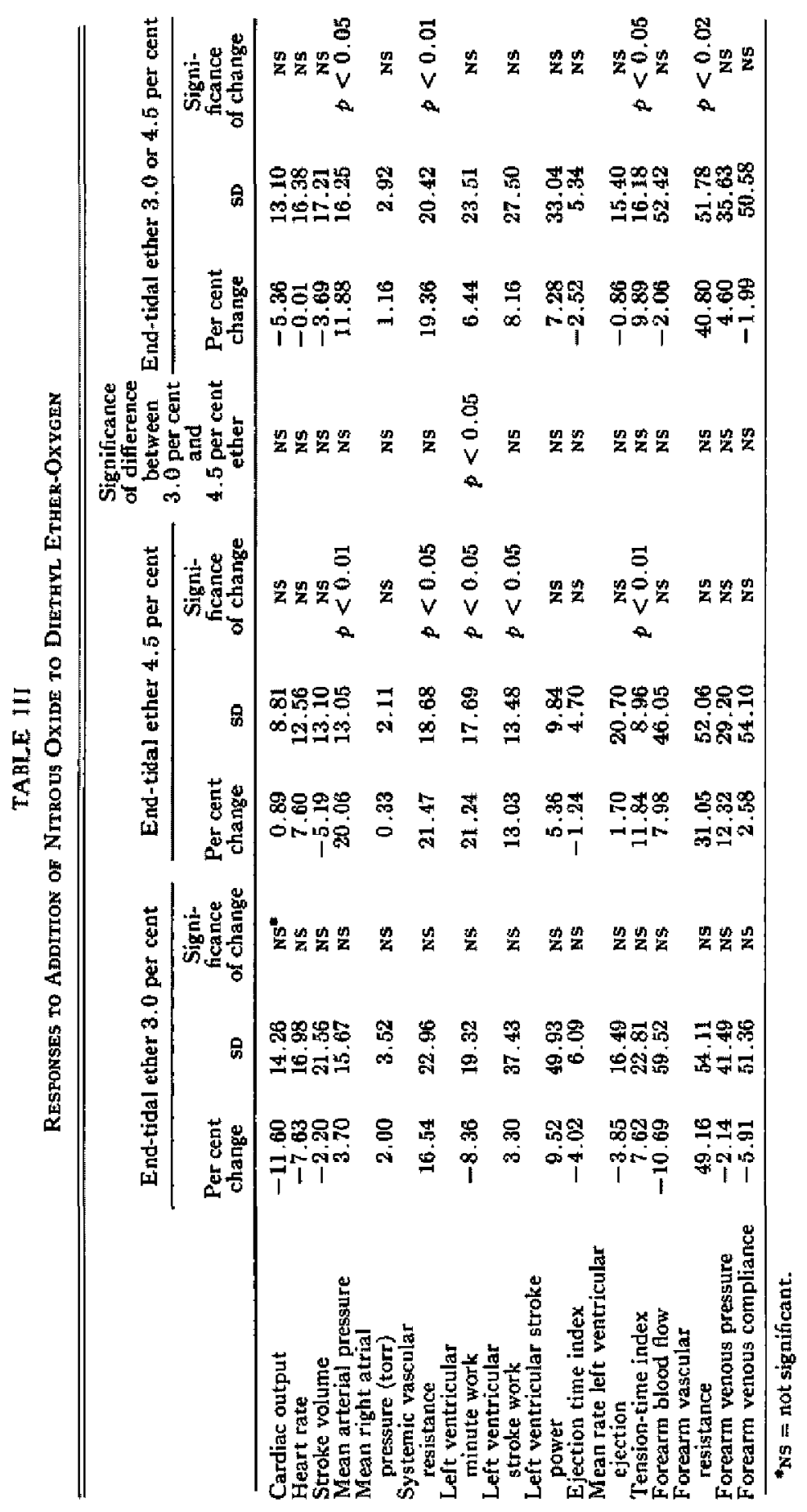


than with halothane to the nonspecific stimulus of the sympathetic nervous system. On the other hand, sympathetic activation may have been maximal during ether anaesthesia in these young subjects, as indicated by the markedly dilated pupils. If this were true, then further stimulation could produce no effect. However, although fluroxene also has a sympathomimetic tendency equal to or exceeding that of diethyl ether ${ }^{9,6}$ the addition of $\mathrm{N}_{2} \mathrm{O}$ to fluroxene-oxygen anaesthesia produced a greater response than with an equivalent concentration of ether-oxygen. ${ }^{\text {t }}$

The vasoconstrictor response to $\mathrm{N}_{2} \mathrm{O}$ was seen only at the deeper level of ether anaesthesia. A somewhat enhanced response was also noted at deep halothane levels. Our observations with ether tend to eliminate a theory advanced with halothane, that lower initial values were responsible for the greater percent changes. The initial values just before the addition of $\mathrm{N}_{2} \mathrm{O}$, were considerably greater with ether than with halothane. ${ }^{3}$

The similarity of reaction of $\mathrm{N}_{2} \mathrm{O}$ seen with ether and halothane would suggest that $\mathrm{N}_{2} \mathrm{O}$ per se is a direct or indirect alpha-adrenergic stimulating agent. However, the addition of $\mathrm{N}_{2} \mathrm{O}$ to fluroxene anaesthesia is accompanied by both $\alpha$ and $\beta$-adrenergic stimulating effects. ${ }^{7}$ Thus, $\mathrm{N}_{2} \mathrm{O}$ must be studied as the sole anaesthetic agent before any conclusions can be drawn as to its circulatory effects.

Body temperature remained constant during the addition of $\mathrm{N}_{2} \mathrm{O}$ to ether, whereas, added to halothane, $\mathrm{N}_{2} \mathrm{O}$ produced a significant and relatively rapid increase. It has been suggested that the combination of $\mathrm{N}_{2} \mathrm{O}$ and a fluorinated hydrocarbon may induce or augment malignant hyperthermia. ${ }^{8}$ The lack of a temperature response with ether and the presence of such a response with halothan strengthens this proposition.

\section{RÉSUMÉ}

Chez des jeunes sujets en bonne santé, on a étudié ce qui se produit si on ajoute a une anesthésie à l'éther bien établie 70 pour cent de protoxyde d'azote ou d'azote. Le fait de changer la concentration d'oxygène en ajoutant de l'azote à 4.5 pour cent d'éther n'affecta que le rythme cardiaque, qui s'est légèrement accéléré. Le protoxyde d'azote ajouté à 3 pour cent d'éther ne produisit aucun effet, mais ajouté à 4.5 pour cent d'éther, il augmenta la pression artérielle moyenne, la résistance vasculaire systémique, le travail minute du ventricule gauche et lindex de tension. Les pupilles furent légèrement dilatées. Ainsi, le protoxyde d'azote avec l'éther a produit des signes de stimulation du récepteur alpha-adrénergique, semblables à ceux qu'on observe avec l'halothane, mais ne présenta pas les effets bêta qu'on observe avec le fluroxene.

\section{ACKNOWLEDGEMENTS}

The authors gratefully acknowledge the technical assistance of Mr Richard Shargel and Miss Dianne Impelman.

\section{REFERENCES}

1. Smith, N. Ty, Eger, E, I., I, Stoeltinc, R. K., Whayne, T. F., Cullen, D., \& Kadis, 
L. B. The cardiovascular and sympathomimetic responses to the addition of nitrous oxide to halothane in man. Anesthesiology, 32: 410-421 (1970),

2. Smrth, N. TY, Eger, E. I., i, Stoecting, R. K., Whrtcher, C. E. Cardiovascular effects of halothane in man. Studies during induction and sudden changes in concentration. JAMA, 206: 1495-1499 (1968).

3. Eger, E. I., II, SMith, N. Ty, Cuxl.en, D. I., Gullen, B. F., \& Ghesony, G. A. A comparison of the cardiovascular effects of halothane, fluroxene, ether and cyclopropane in man: A resumé. Anesthesiology, 34: 25-41 (197I).

4. Altman, P. L. \& Ditrmen, D. S. (Eds): Environmental Biology. Baltimore, Federation of American Societies for Experimental Biology (1966) pp. 404-405.

5. Price, H. L. Circulation during anesthesia and operation. Springfield, Ill., Charles C. Thomas (1967).

6. SMith, N. Ty, Ecer, E. I., Ir, Cullen, B. F., SAwren, D. C., \& Gnegony, G. A. The catdiovascular responses to the addition of nitrous oxjde to fluroxene in man, Brit. J. Anaesth., in press (1972).

7. Cullen, B. F., Egen, E. I, II, Smith, N. Ty, Sawyen, D. C., Gregony, G. A. \& Johs, T. A. Cardiovascular effects of fluroxene in man. Anesthesiology 32: 218-230 (1970).

8. Harmison, G. G., Biebuxck, J. F., Terblanche, J., Dent, D. M., Hickman, R., \& Saunders, S. J. Hyperpyrexia during anesthesia, Brit. M. J. 3: 594 ( 1968 ). 